\title{
Purification of a New Anticoagulant Protein, Calphobindin III, from Human Placenta
}

\author{
Hirokazu Sato \\ Department of Obstetrics and Gynecology, School of \\ Medicine, Akita University, Akita 010
}

\begin{abstract}
Sato, H. Purification of a New Anticoagulant Protein, Calphobindin III, from Human Placenta. Tohoku J. Exp. Med., 1992, 168 (4), 561-572 — The $\mathrm{Ca}^{2+}$-phospholipid binding proteins in human placental tissue were investigated with the binding of a placental EDTA extract to liposomes composed of placental phospholipids. A new $\mathrm{Ca}^{2+}$-dependent phospholipid-binding protein different from calphobindin I (CPB I) and calphobindin II (CPB II) was isolated from the EDTA extract, and the purification procedure of this protein was established. The yield of the purified protein was about $1.2 \mathrm{mg}$ from one placenta. The protein prolonged the clotting time of normal plasma when coagulation was induced by tissue factor and ellagic acid. This protein had an apparent molecular weight of 32,000 as determined by sodium dodecyl sulfate-polyacrylamide gel electrophoresis under reducing conditions, and its isoelectric point was 5.8. Because of its ability to bind phospholipids in the presence of $\mathrm{Ca}^{2+}$, this protein was designated as calphobindin III (CPB III). $\longrightarrow \mathrm{Ca}^{2+}$-dependent phospholipid-binding protein ; calphobindin ; annexin ; anticoagulant; purification
\end{abstract}

The placenta is rich in coagulation promoters, for example, tissue factor (Gonmori and Takeda 1976) and factor XIII-like substance (Soria et al. 1974) : and in fibrinolysis inhibitors, for example, urokinase inhibitor (Kawano et al. 1986). Moreover, pregnancy is both in a dominant state of coagulation and in a poor state of fibrinolysis (Maki et al. 1980). Thus it would appear that thrombosis and infarction should take place frequently in the intervillous spaces; however, they happen only rarely. This would imply that anticoagulant factors exit in placental tissue.

From human placenta was isolated a new anticoagulant protein that prolongs the clotting time of normal plasma induced by tissue factor and ellagic acid (Shidara et al. 1983; Shidara 1984). Its calculated molecular weight is 35,731 and its isoelectric point is 4.9. Because of its ability to bind phospholipid in the presence of $\mathrm{Ca}^{2+}$, this protein was named calphobindin I (CPB I) (Shidara and Iwasaki 1988). Employment of this binding property allowed purification of

Received April 22, 1991 ; revision accepted for publication November 5, 1992.

Address for reprints : Hirokazu Sato, Department of Obstetrics and Gynecology, School of Medicine, Akita University, Akita 010, Japan.

Director : Prof. M. Maki. 
CPB I with a high recovery rate, and moreover, it led to the isolation of another anticoagulant protein named calphobindin II (CPB II). CPB II also presents the $\mathrm{Ca}^{2+}$-dependent binding to phospholipid and has an apparent molecular weight of about 73,000 and an isoelectric point of 6.4 (Kume 1989). The author therefore postulated that the EDTA extract of human placental tissue, which yielded CPB I and CPB II, might contain other anticoagulant proteins exhibiting $\mathrm{Ca}^{2+}$-dependent binding to phospholipids. By using phospholipid vesicles (liposomes) made from placental phospholipids, the author screened for other anticoagulant proteins in the EDTA extract and found a third protein named calphobindin III (CPB III). In this report, purification and physicochemical properties of CPB III are described.

\section{Materials and Methods}

\section{Isolation of $C P B$ III}

The existence of a new $\mathrm{Ca}^{2+}$-dependent phospholipid-binding protein different from CPB I and CPB II is demonstrated in the EDTA extract of human placenta tissue. All the isolation procedures were carried out at $4^{\circ} \mathrm{C}$.

Preparation of placental EDTA extract. Four fresh and full-term human placentae (about 1,400 g), from which the umbilical cord and amniotic membrane were removed, were cut into cubes and washed with 5 liters of $50 \mathrm{mM}$ Tris- $\mathrm{HCl}(\mathrm{pH} 7.4)$ containing $5 \mathrm{mM} \mathrm{CaCl} 2$ (buffer A) to remove the blood. The washed placental tissue was homogenized with a Waring blender in 4 liters of buffer $\mathrm{A}$ for $5 \mathrm{~min}$, and the homogenate was centrifuged at $10,000 \times \mathrm{g}$ for $15 \mathrm{~min}$. After washing the placental debris twice, it was rehomogenized in 1 liter of $50 \mathrm{mM}$ Tris- $\mathrm{HCl}(\mathrm{pH} 7.4)$ containing $50 \mathrm{mM}$ EDTA and centrifuged at $10,000 \times \mathrm{g}$ for 15 min. The supernatant was dialyzed overnight against three changes of 4 liters of $50 \mathrm{mM}$ Tris- $\mathrm{HCl}(\mathrm{pH} \mathrm{7.4)}$ and designated as the EDTA extract. The extract was concentrated and stored at $-30^{\circ} \mathrm{C}$ until needed. Protein concentrations were measured by the Bradford method (1976).

Preparation of liposomes. All the procedures were carried out at $4^{\circ} \mathrm{C}$. Placental phospholipid was extracted by a modification of the method of Nemerson and Pitlick (1970). A placenta frozen at $-40^{\circ} \mathrm{C}$ was thawed and washed in $0.15 \mathrm{M} \mathrm{NaCl}$ followed by removal of the umbilical cord and amniotic membrane. It was then cut into cubes. After homogenizing in a Waring blender in an equal volume of acetone, it was stirred for $30 \mathrm{~min}$ and then filtered through Whatman No. 1 paper. The placental debris was washed 5 times and then dried. This debris was rehomogenized in $20 \mathrm{ml} / \mathrm{g}$ of heptane : butanol $(2: 1, \mathrm{v} / \mathrm{v})$ and then filtered with Whatman No. 42 paper to yield placental phospholipid (filtrate). The phospholipid components were analyzed by two dimensional thin layer chromatography according to the method of Gray (1967). Then cell-sized monolayer liposomes were prepared by the method of Goto and Sato (1980).

Liposome binding experiment. $\mathrm{Ca}^{2+}$-dependent phospholipid-binding proteins were isolated using liposomes as the carrier of the proteins. The placental EDTA extract $(0.5$ $\mathrm{mg} / \mathrm{ml})$ and liposomes $(0.25 \mathrm{mg} / \mathrm{ml})$ were incubated at $37^{\circ} \mathrm{C}$ for $15 \mathrm{~min}$ in $200 \mathrm{ml}$ of $50 \mathrm{mM}$ Tris- $\mathrm{HCl}$ (ph 7.4) containing $5 \mathrm{mM} \mathrm{CaCl}$ and then centrifuged at $100,000 \times \mathrm{g}$ for $15 \mathrm{~min}$. The pellet was homogenized in $200 \mathrm{ml}$ of $50 \mathrm{mM}$ Tris- $\mathrm{HCl}\left(\mathrm{pH}\right.$ 7.4) containing $5 \mathrm{mM} \mathrm{CaCl}_{2}$ and the homogenate was centrifuged again. The pellet was sonicated with a Branson Model W-185 (Danbury, CT, USA) for $2 \mathrm{~min}$ in $200 \mathrm{ml}$ of $50 \mathrm{mM}$ Tris- $\mathrm{HCl}$ (pH 7.4) containing 50 mM EDTA. After the same incubation and centrifugation, the supernatant containing the $\mathrm{Ca}^{2+}$-dependent phospholipid binding proteins was dialyzed against $50 \mathrm{mM}$ Tris- $\mathrm{HCl}(\mathrm{pH}$ 7.4) to eliminate EDTA. 
Q-Sepharose column chromatography. The dialyzed sample was applied to a column $(3.0 \times 5.0 \mathrm{~cm})$ of Q-Sepharose Fast Flow (Pharmacia, Uppsala, Sweden) equilibrated with 50 $\mathrm{mM}$ Tris- $\mathrm{HCl}(\mathrm{pH} \mathrm{7.4})$ at a flow rate of $100 \mathrm{ml} / \mathrm{hr}$. The proteins were eluted with a linear gradient of 0 to $0.5 \mathrm{M} \mathrm{NaCl}$ in $50 \mathrm{mM}$ Tris-HCl $(\mathrm{pH} \mathrm{7.4)}$; protein concentration was monitored by absorbance at $280 \mathrm{~nm}$.

Assay of anticoagulant activity. The anticoagulant activities of samples were measured by using a modified prothrombin time (PT) and modified activated partial thromboplastin time (APTT). Fibrin clot formation for both the PT and APTT was assayed by the optical detection method, at $37^{\circ} \mathrm{C}$ in a glass cuvette with a CP-7A coagulation profiler (BIO/ DATA, Horsham, PA, USA). For the measurement of APTT, $100 \mu \mathrm{l}$ of a sample was combined with $50 \mu \mathrm{l}$ of citrated human plasma, and preincubated for $1 \mathrm{~min}$ at $37^{\circ} \mathrm{C}$. After the addition of $50 \mu 1$ of APTT reagent (Cephotest; Eisai, Tokyo), the mixture was incubated for $6 \mathrm{~min}$ and coagulation was started by the addition of $100 \mu 1$ of $0.02 \mathrm{M} \mathrm{CaCl}_{2}$. For the measurement of PT, $100 \mu \mathrm{l}$ of a sample was mixed with $100 \mu \mathrm{l}$ of PT reagent (Lyoplastin; Mochida, Tokyo) which had been diluted to $0.25 \mathrm{mg} / \mathrm{ml}$ with $0.01 \mathrm{M} \mathrm{CaCl}_{2}$. After incubation for 2 min, coagulation was started by the addition of $100 \mu$ l of citrated human plasma (Ci-trol ; Baxter, Miami, FL, USA).

Two-dimensional electrophoresis. The isoelectric point and molecular weight of CPB III was determined by two-dimensional electrophoresis according to the method of O'Farrell (1975) using the Two-Dimensional Electrophoresis System (M \& S Instruments Trading Ins., Osaka). The first dimension consisted of polyacrylamide gel isoelectric focusing with Pharmalyte 5-8 and Pharmalyte 3-10 (Pharmacia) as carrier ampholytes. The second dimension was standard sodium dodecyl sulfate-polyacrylamide gel electrophoresis (SDSPAGE) according to the method of Laemmli (1970). After completion of the twodimentional electrophoresis, the gel was stained with Coomassie Brilliant Blue R (Sigma, St. Louis, MO, USA). The pI markers used were pI calibration kit Electran (range 4.7-10.6 ; BHD Ltd., Poole, England), while the molecular weight markers were from Pharmacia LMW kit E.

\section{Purification of $C P B I I I$}

Because the recovery rate of CPB III in the liposome binding protocol was very poor, the following modifications were made for the purification of CPB III. All the purification procedures were carried out at $4^{\circ} \mathrm{C}$. The starting material was similar to the EDTA extract prepared in the liposome binding protocol except that the washing of the placental debris was performed only twice and the EDTA extract was not dialyzed. The proteins precipitated by $30 \%-80 \%$ ammonium sulfate were dialyzed overnight against an excess of $50 \mathrm{mM}$ Tris- $\mathrm{HCl}(\mathrm{pH} 7.4)$. The dialyzed sample was applied to a column $(5.0 \times 7.6 \mathrm{~cm})$ of $\mathrm{Q}$ Sepharose Fast Flow (Pharmacia) equilibrated with $50 \mathrm{mM}$ Tris-HCl (pH 7.4). After washing the column with the buffer, it was eluted at a flow rate of $200 \mathrm{ml} / \mathrm{hr}$ with a linear gradient generated with 1 liter of $50 \mathrm{mM}$ Tris-HCl $(\mathrm{pH}$ 7.4) and 1 liter of the same buffer containing $0.5 \mathrm{M} \mathrm{NaCl}$. The eluate was collected in $10 \mathrm{ml}$ fractions. Each fraction was analyzed by SDS-PAGE, and its anticoagulant activity on the PT and APTT was tested. The fractions corresponding to the minor active peak, which were eluted at $0.1 \mathrm{M} \mathrm{NaCl}$, were collected and concentrated to $5 \mathrm{ml}$ by ultrafiltration using a Diaflo membrane YM10 (Amicon, Danvers, Ireland). The concentrated sample was loaded onto a column $(2 \times 90$ $\mathrm{cm}$ ) of Sephadex G-100 (Pharmacia) equilibrated with $50 \mathrm{mM}$ Tris-HCl (pH 7.4). The flow rate was maintained at $30 \mathrm{ml} / \mathrm{hr}$ and at $5 \mathrm{ml}$ fractions were collected. The fractions which had the major anticoagulant activity as determined by PT were dialyzed against $25 \mathrm{mM}$ sodium acetate buffer ( $\mathrm{pH}$ 5.2) and applied to a Mono S HR 5/5 column (FPLC system, Pharmacia) equilibrated with the same acetate buffer. The column was developed with a $30-\mathrm{ml}$ linear gradient of 0 to $0.4 \mathrm{M} \mathrm{NaCl}$ at a flow rate of $1 \mathrm{ml} / \mathrm{min}$, and $0.5-\mathrm{ml}$ fractions were collected. 


\section{RESULTS}

\section{Isolation of $C P B I I I$}

The washing with $50 \mathrm{mM}$ Tris- $\mathrm{HCl}$ containing $5 \mathrm{mM} \mathrm{CaCl}_{2}$ (pH 7.4) eliminated $\mathrm{Ca}^{2+}$-independent proteins such as albumin, globulin and hemoglobin from the placental tissue. The washing steps were essential to remove excess quantities of these proteins. The three major proteins obtained from the EDTA extract had molecular weights of $32,000,34,000$ and 68,000 . The phospholipid extracted from human placentae was composed of phosphatidy-lethanolamine $(15.3 \%)$, phosphatidylcholine $(41.5 \%)$ and sphingomyelin $(43.2 \%)$. Most of the liposomes made from the placental phospholipid were cell-sized, measuring between 1 and $100 \mu \mathrm{m}$ in diameter. Ethanol added during the preparation of the liposomes had no effect on the isolation of CPB III.

The SDS-PAGE of each step of the liposome binding purification is shown in Fig. 1. The three major proteins of molecular weights of $32,000,34,000$ and 68,000 bind to liposomes, since the addition of liposomes causes them to precipitate and nearly to disappear from the supernatant (Fig. 1, lane 2). The binding appears to be $\mathrm{Ca}^{2+}$-dependent, since incubation with a $\mathrm{Ca}^{2+}$ chelator prevents them from binding to and precipitating with the liposomes (Fig. 1, lane 4).

Three major protein peaks which maintained anticoagulant activity were obtained by Q-Sepharose column chromatography with a linear gradient of $\mathrm{NaCl}$

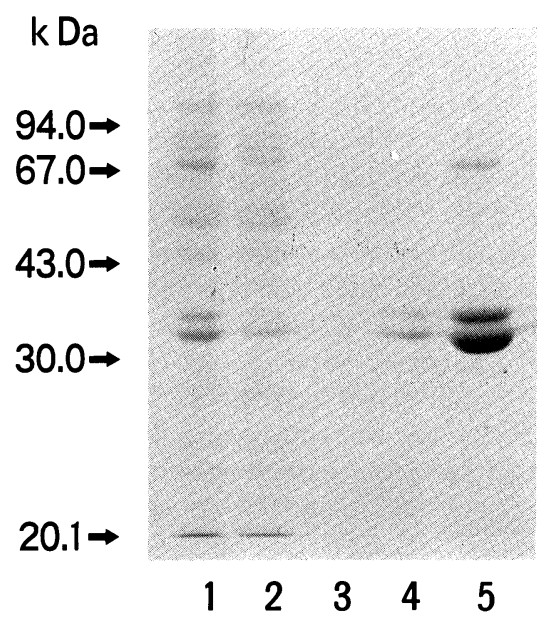

Fig. 1. The SDS-PAGE (10\% gel) of fractions in the liposome binding experiment. Lane 1, placental EDTA extract; lane 2, supernatant of the placental extract after liposome binding ; lane 3, supernatant in washing liposomes after the binding experiment; lane 4, EDTA extract from washed liposomes; lane 5, concentrate of EDTA extract from washed liposomes. The 32-, 34-, and $74-\mathrm{kDa}$ proteins decreased in the supernatant after liposome binding and appeared again in the EDTA extract. 


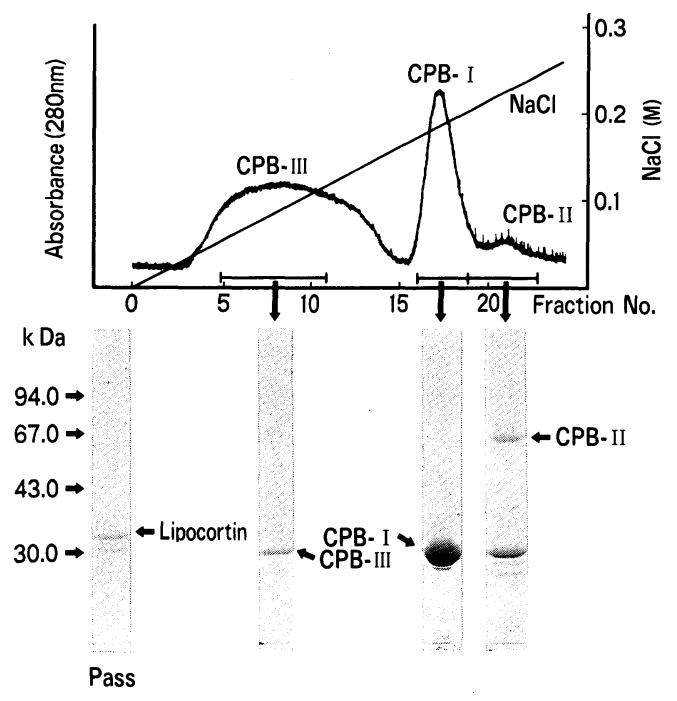

Fig. 2. Separation of CPB III by Q-Sepharose column chromatography after the liposome binding experiment and the SDS-PAGE of each fraction. "Pass" indicates the pass through fraction including lipocortin.
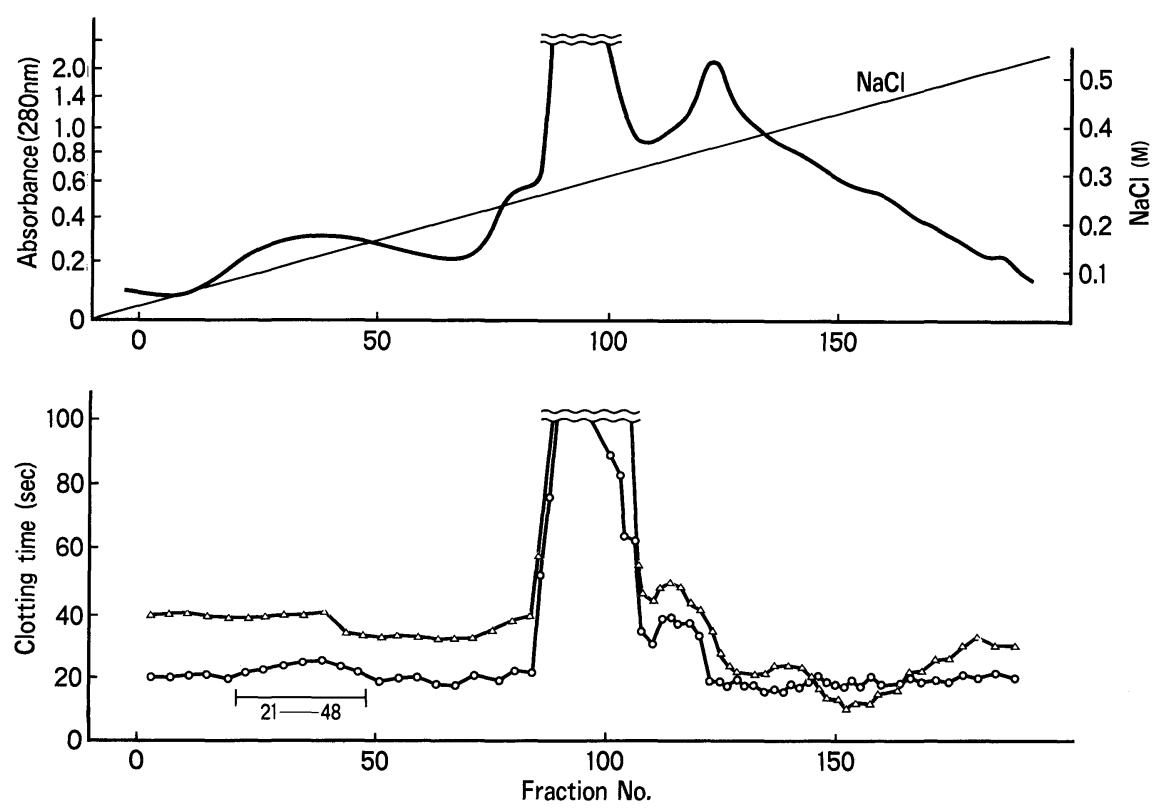

Fig. 3. Elution pattern of Q-Sepharose column chromatography and anticoagulant effect of each fraction on PT $(\bigcirc-\bigcirc)$ and APTT $(\triangle-\triangle)$. The first anticoagulant peak corresponding to the fractions No. 21-48 included CPB III. 
(Fig. 2). The protein peaks which were eluted at $0.18 \mathrm{M}$ (the second peak) and $0.20 \mathrm{M}$ (the third peak) $\mathrm{NaCl}$ were identified as CPB I and CPB II, respectively, by their molecular weights, column elution patterns, isoelectric point and immunological cross-reactivities. On the other hand, the first peak protein eluted at $0.10 \mathrm{M} \mathrm{NaCl}$ migrated as a single band with a molecular weight of 32,000 estimated by SDS-PAGE under reducing conditions. Because this smaller protein was different from CPB I and CPB II immunologically as confirmed by electroblotting using the monoclonal and kolyclonal antibodies, we designated this new $\mathrm{Ca}^{2+}$-dependent phospholipid-binding protein calphobindin III (CPB III).

\section{Purification of $C P B I I I$}

Placental EDTA extract contained at least three anticoagulant proteins which could be precipitated with ammonium sulfate and resolved by Q-Sepharose column chromatography. They eluted at $0.10 \mathrm{M}, 0.18 \mathrm{M}$ and $0.20 \mathrm{M} \mathrm{NaCl}$ (Fig. 3). The second and third peaks were identified as CPB I and CPB II in a number of ways including immunological cross-reactivity. The first peak corresponding to the fractions No. 21-48 included a $32-\mathrm{kD}$ a protein which was presumed to be CPB III. These fractions were concentrated and applied to a gel filtration column of Sephadex G-100. Two broad peaks were resolved. Anticoagulant activity (mea-

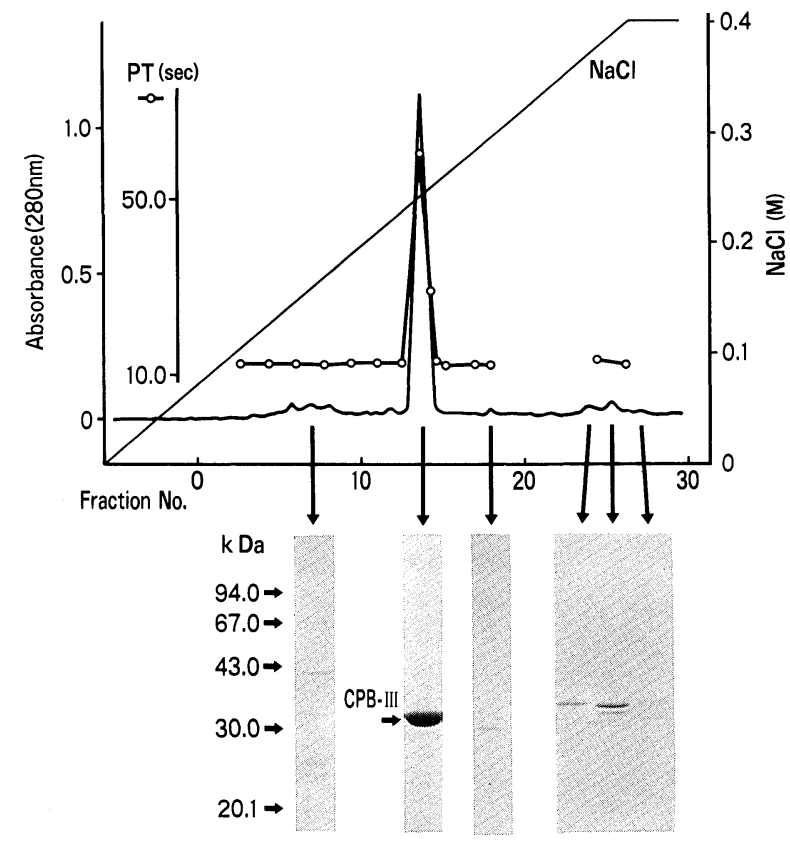

Fig. 4. Mono S column chromatography and anticoagulant efflect of effiuents on PT. The SDS-PAGE of fractions indicated by the arrows was shown at the bottom. CPB III eluted at $0.24 \mathrm{M} \mathrm{NaCl}$ and migrated as a single band on SDS-PAGE. 
sured with PT) was found in the second peak. SDS-PAGE of each fraction indicated that the $78-\mathrm{kDa}$ protein was the main protein in the first peak and the $32-\mathrm{kDa}$ CPB III resided in the second peak. The pooled CPB III fractions were applied to a Mono S column (Fig. 4). CPB III eluted at $0.24 \mathrm{M} \mathrm{NaCl}$ and

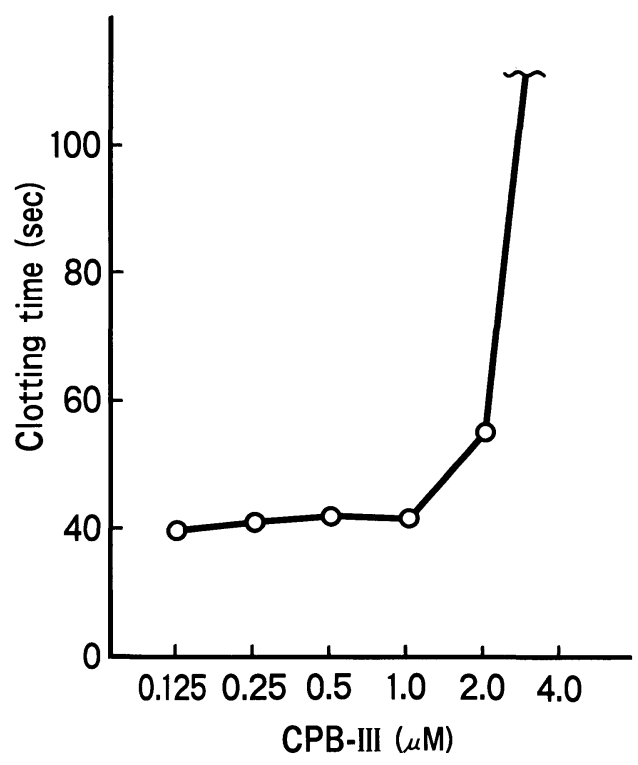

Fig. 5. Effect of CPB III on activated partial thromboplastin time (APTT). Measurement procedure of APTT is described under "Materials and Methods".

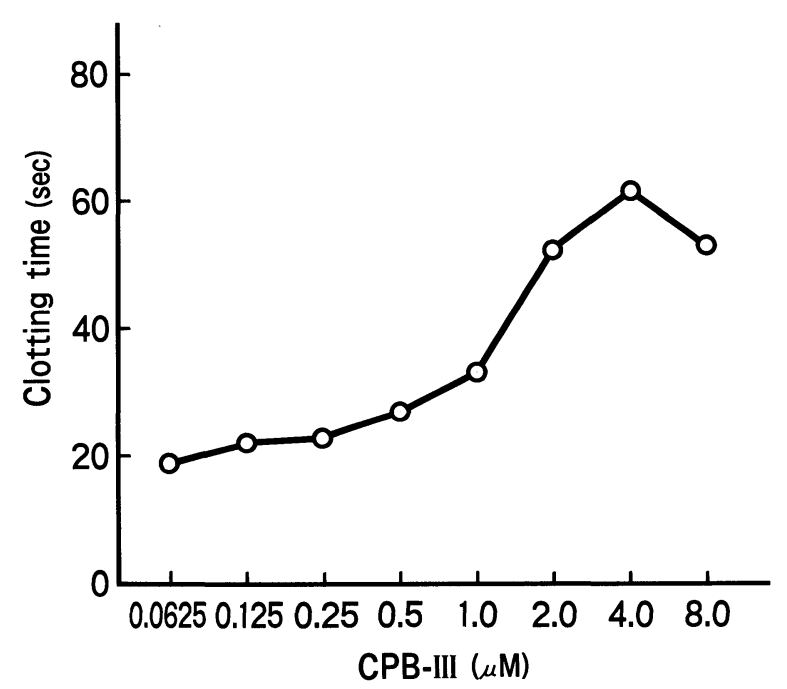

Fig. 6. Effect of CPB III on prothrombin time (PT). Measurement procedure of PT is described under "Materials and Methods". 


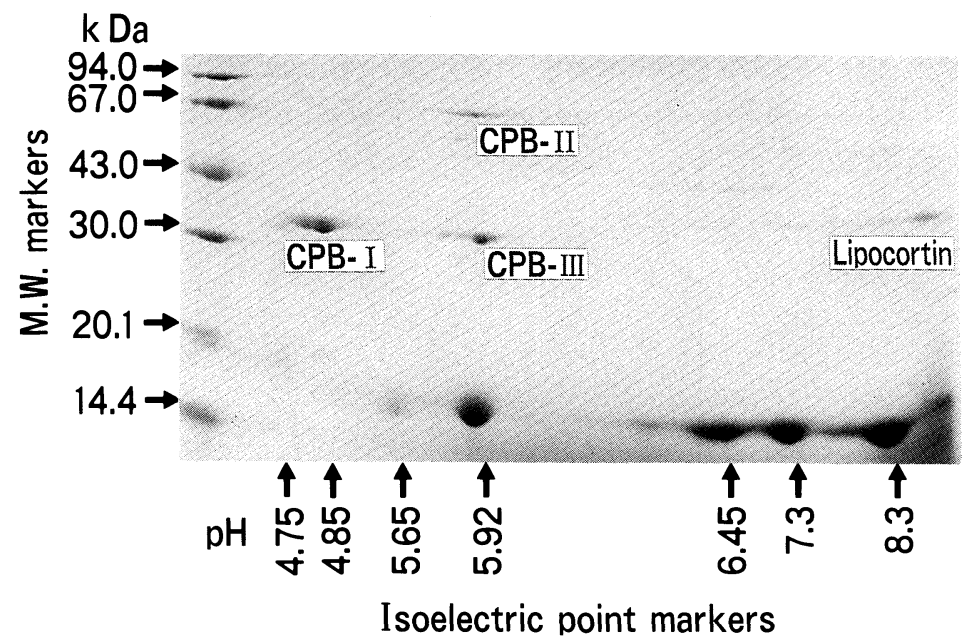

Fig. 7. Two-dimensional electrophoresis of CPB I, II, III and lipocortin.

migrated as a single band on SDS-PAGE. Anticoagulant activity also corresponded to this peak. The yield of purified protein was approximately $1.2 \mathrm{mg}$ from one placenta.

\section{Functional and physicochemical properties of CPB III}

CPB III at concentrations higher than $2.0 \mu \mathrm{M}$ prolonged APTT in a dosedependent manner, and $4.0 \mu \mathrm{M} \mathrm{CPB} \mathrm{III} \mathrm{inhibited} \mathrm{clot} \mathrm{formation} \mathrm{for} \mathrm{at} \mathrm{least} 120$ sec (Fig. 5). Similarly CPB III or $0.5 \mu \mathrm{M}$ or more prolonged PT, and the clotting time reached a plateau at $4.0 \mu \mathrm{M} \mathrm{CPB}$ III (Fig. 6). From this, the author concludes that CPB III can inhibit both the intrinsic and extrinsic pathways. CPB III has an isoelectric point of 5.9 and an apparent molecular weight of 32,000 (Fig. 7).

\section{Discussion}

In this study, a new $\mathrm{Ca}^{2+}$-dependent phospholipid-binding protein named CPB III was isolated from human placental EDTA extract by using liposomes prepared from placental phospholipids as the adsorbent. In 1987, Fauvel et al. purified a $\mathrm{Ca}^{2+}$-dependent phospholipid binding protein (named endonexin) from the EDTA extract of bovine liver with a phosphatidylserine-immobilized column. This protein demonstrated inhibitory activity toward phospholipase $\mathbf{A}_{2}$. During the course of our study on the anticoagulant mechanism at the intervillous space, two anticoagulant proteins, CPB I and CPB II, which bind to acidic phospholipids in the presence of $\mathrm{Ca}^{2+}$, were purified (Shidara et al. 1983; Kume 1989) and their amino acid sequences were determined (Iwasaki et al. 1987, 1989). The fact that CPB I was a $\mathrm{Ca}^{2+}$-dependent phospholipid-binding protein which could 


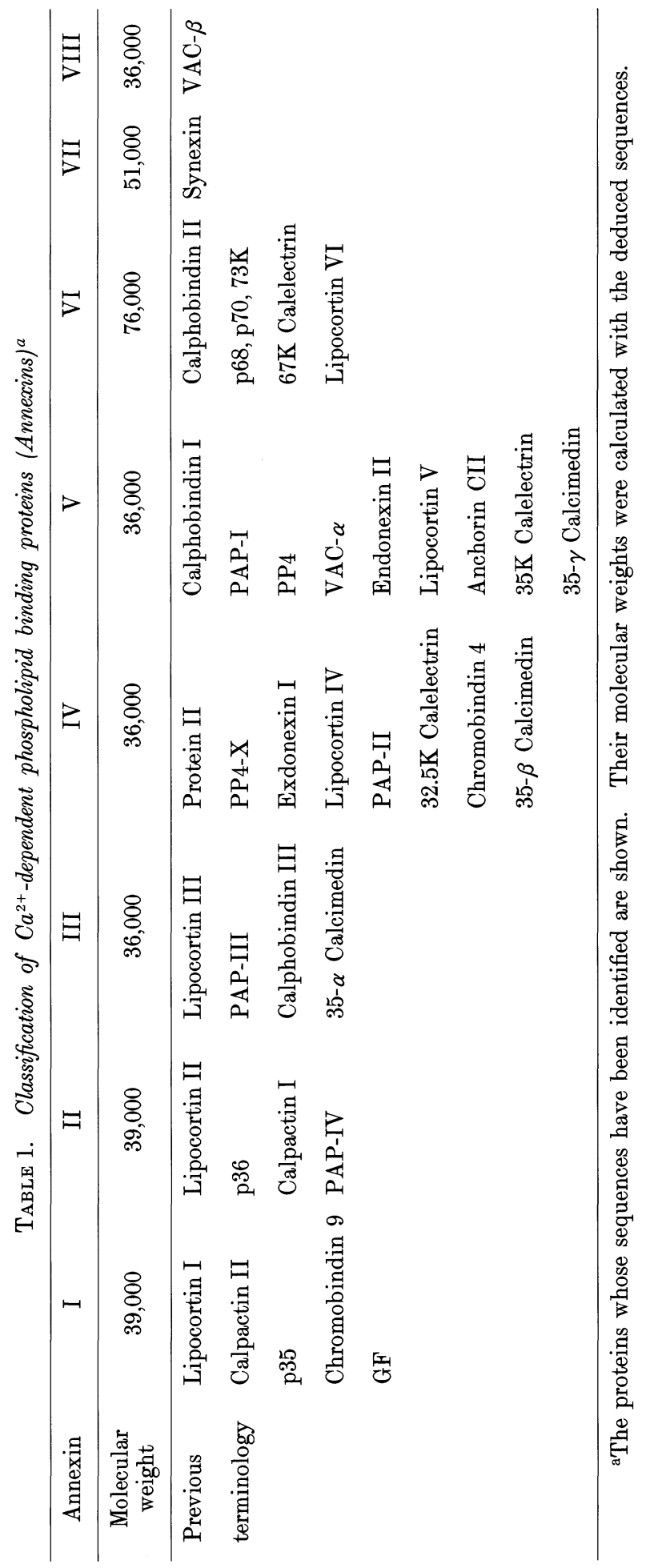


be solubilized easily with EDTA from human placental homogenate led to the high recovery rate of CPB I and to the purification of CPB II which had the same property. Therefore, the author tried to isolate new $\mathrm{Ca}^{2+}$-dependent phospholipid-binding proteins different from CPB I and CPB II by use of placental tissue itself, which was washed many times with $\mathrm{Ca}^{2+}$ containing buffer, as a ligand for the $\mathrm{Ca}^{2+}$-dependent phospholipid-binding proteins. However, the repeated washings did not remove the major contaminating proteins in the placental tissue completely but did lead to the loss of the $\mathrm{Ca}^{2+}$-dependent phospholipid-binding proteins such as CPB I and CPB II. Consequently, the liposomes composed of placental phospholipids (containing $15 \%$ of acidic phospholipids) were employed as a ligand to isolate other $\mathrm{Ca}^{2+}$-dependent phospholipid-binding proteins from the placental EDTA extract.

It seems likely that CPB III, which shows the anticoagulant activity, is a protein because it could be stained with standard protein staining methods such as Coomassie brilliant blue and silver stainings, it could be quantitated with the Bradford and the Lowry methods, and it had maximum absorption at $280 \mathrm{~nm}$. The isoelectric point was further determined in FPLC system with a Mono $\mathrm{P}$ column (Pharmacia) to be 5.71. Recently, many researchers have reported various types of $\mathrm{Ca}^{2+}$-dependent phospholipid binding proteins which were designated independently (Table 1). These proteins were classified according to their molecular weights, isoelectric points and amino acid sequences. Their names are going to be unified as annexins. In Table 1, annexin III is the most analogous to CPB III. PAP III, which belongs to this group, was purified from human placenta by Tait et al. (1988) and had a molecular weight of 34,000 on SDS-PAGE. Its isoelectric point was 5.9 by isoelectric focusing. It also possessed anticoagulant activity. Although its partial amino acid sequence has been determined, its isoelectric point and its elution pattern of a Mono $\mathrm{S}$ column are different from those of CPB III. Unfortunately there is no other detailed report about its physiological activity. Amino acid sequencing of CPB III will be necessary to confirm whether or not CPB III and PAP III are different proteins.

In this study, CPB III was purified with four steps including fractionation with ammonium sulfate, ion exchange chromatography, gel filtration and ion exchange chromatography (FPLC system). The first and second steps were the same as for the purification of CPB I and CPB II. However, the anticoagulant activity of the CPB III fractions in the second step was very weak making it difficult to detect. CPB III and a $78 \mathrm{~K}$ dalton protein eluted from a Q-Sepharose column between $0-0.3 \mathrm{M} \mathrm{NaCl}$. These two proteins were resolved by the third step (gel filtration). After the final step (ion exchange chromatography), CPB III migrated as a single band on SDS-PAGE. Although this chromatography was performed at $\mathrm{pH}$ 5.2, no degradation was apparent. We attempted to substitute a Mono Q (Pharmacia) for the Mono S column, but the separation rate was too poor. 


\section{Acknowledgments}

I wish to thank Drs. Makoto Murata and Yoshihiro Shidara for their guidance and thoughtful advice.

\section{References}

1) Bradford, M.M. (1976) A rapid and sensitive method for the quantitation of microgram quantities of protein utilizing the principle of protein-dye binding. Anal. Biochem., 72, 248-254.

2) Fauvel, J., Salles, J.P., Roques, V., Chap, H., Rochat, H. \& DousteBlazy, L. (1987) Lipocortin-like anti-phospholipase A2 activity of endonexin. FEBS Lett., 216, 4550 .

3) Gonmori, H. \& Takeda, Y. (1976) Properties of human tissue thromboplastins from brain, lung, arteries and placenta. Thromb. Haemost., 36, 90-103.

4) Goto, K. \& Sato, H. (1980) Formation of cell-sized single-layered liposomes in a simple system of phospholipid, ethanol and water. Tohoku J. Exp. Med., 131, 399407.

5) Gray, G.M. (1967) Chromatography of lipids. V. The quantitative isolation of the minor (acidic) phospholipids and of phosphatidylethanolamine from the lipid extracts of mammalian tissues. Biochim. Biophys. Acta, 144, 519-524.

6) Iwasaki, A., Suda, M., Nakao, H., Nagoya, T., Saino, Y., Arai, K., Mizuguchi, T., Sato, F., Yoshizaki, H., Hirata, M., Miyata, T., Shidara, Y., Murata, M. \& Maki, M. (1987) Structure and expression of cDNA for an inhibitor of blood coagulation isolated from human placenta: A new lipocortin-like protein. J. Biochem., 102, 1261-1273.

7) Iwasaki, A., Suda, M., Watanabe, M., Nakao, H., Hattori, Y., Nagoya, T., Saino, Y., Shidara, Y. \& Maki, M. (1989) Structure and expression of cDNA for calphobindin $\mathrm{U}$, a human placental coagulation inhibitor. J. Biochem., 106, 43-49.

8) Kawano, T., Morimoto, K. \& Uemura, Y. (1986) Urokinase inhibitor in human placenta. Nature, 217, 253-254.

9) Kume, K. (1989) Isolation of calphobindin II and its mechanism of anticoagulant activity. Acta Obstet. Gynaec. Jpn., 41, 1537-1544. (in Japanese with English abstract)

10) Laemmli, U.K. (1970) Cleavage of structural proteins during the assembly of the head of bacteriophage T4. Nature, 227, 680-685.

11) Maki, M., Soga, K. \& Seki, M. (1980) Fibrinolytic activity during pregnancy. Tohoku J. Exp. Med., 132, 349-354.

12) Nemerson, Y. \& Pitlick, F.A. (1970) Purification and characterization of the protein component of tissue factor. Biochemistry, 9, 5100-5105.

13) O'Farrell, P.H. (1975) High resolution two-dimensional electrophoresis of proteins. J. Biol. Chem., 250, 4007-4021.

14) Shidara, Y. (1984) Isolation and purification of placental coagulation inhibitor. Acta Obstet. Gynaec. Jpn., 36, 2583-2592. (in Japanese with English abstract)

15) Shidara, Y. \& Iwasaki, A. (1988) Structure and expression of cDNA for calphobindin. Acta Haematol. Jpn., 51, 1670-1679.

16) Shidara, Y., Murata, M. \& Maki, M. (1983) Purification and characterization of human placental protein with anticoagulant activity. Blood Vessel, 14, 498-500. (in Japanese with English abstract)

17) Soria, J., Soria, C. \& Samama, M. (1974) Placental fibrin stabilization factor. Physio-chemical, immuno-chemical and biological properties. Pathologie-Biologie, 22, Suppl., 86-91.

18) Tait, J.F., Sakata, M., McMullen, B.A., Miao, C.H., Funakoshi, T., Hendrickson, L.E. 
\& Fujikawa, K. (1988) Placental anticoagulant proteins: Isolation and comparative characterization of four members of the lipocortin family. Biochemistry, 27, 62686276 . 